\title{
A esperança cristã e as questões atuais da escatologia: novas leituras e novas abordagens
}

\author{
Orientador: Prof. Cesar Augusto Kuzma
}

Pesquisadora: Luciola Paiva Tisi

Fonte: $\mathrm{CNPq}$

\section{Introdução}

Este projeto de pesquisa traz como proposta a temática da "esperança cristã e as questões atuais da escatologia", realizou-se um estudo a partir de leituras de textos dos autores Leonardo Boff, Joseph Ratzinger, Andrés Torres Queiruga e Jürgen Moltmann para analisar exemplos de pensamento sobre a esperança escatológica cristã baseada na compreensão dos autores citados. $\mathrm{O}$ que detalhamos, de modo específico, é um recorte epistemológico na intenção de buscar novas leituras e novas abordagens, a partir de literaturas previamente selecionadas com o objetivo de trazer a dimensão da esperança como chave de interpretação da escatologia contemporânea, procurando fazer uma síntese textual dos autores estudados, para uma compreensão mais detalhada, que juntamente com as novas abordagens teológicas que surgem em nosso contexto podem oferecer à teologia um novo momento de ação.

\section{Objetivos}

Estudar a esperança cristã e as questões atuais da escatologia. Aprofundar este estudo diante de novas leituras e novas abordagens que possam fomentar a abertura ao ser humano para um sentido e uma nova perspectiva de futuro. Buscar em teólogos atuais nova chave de interpretação que possam oferecer atualização da esperança cristã e as questões atuais da escatologia. 